\title{
Frick Fro (3)
}

\author{
Wanda Coleman
}

Des rythmes et images de jazz et de blues évoquant une sensualité déconcertante et dépeignant le tableau d'une nuit intoxicante qui frémit en rencontrant la mort-dans-la-vie du jour. Plaisir et dépense donneleur place à la certitude dépossédante de la responsabilitéfiscale, des fonds de retraite et des bonds municipaux. De cette contradiction émerge le sujet collectif de ce poème, oint et dansant.

smell the sweat \& suede of the tapdaddies swilling skidrow gin \& bitter lime, and tonk-THAT-muthafucka in praise of liver \& onions served on cracked blue plates by two-toned beauties who hail from those lost kingdoms south of the Mason-Dixon line on this night approaching like armageddon in a half-pint

hit that ill-lit pipe offering up delusions of fiscal responsibility and shudder as dawn kisses the drawn lids of eyes too heavily entranced to be shocked at the machetes amputating extremities ambitiously running rivers of patriotic blood

ooooo. come again

as the sluggishness of a spent desire subsides like the revolt of vexed government employees unqualified to do much more than stamp-and-pass or hiss-and-piss while wallowing in the certainty of retirement funds and municipal bonds as they contaminate the air with "no" (brooding superstitious posers doing the bellyflop in praise of the death zone they enter) 
Frick Fro $\cdot 113$

that we soothspillers may

rise from the homicidal funk

annointed in bullfat \& hemp oil

word-warriors snake dancing in the drum 